\title{
Basic Water Treatment
}


Downloaded by [] on [26/04/23]. Copyright (C ICE Publishing, all rights reserved. 


\section{Basic Water Treatment}

Sixth edition

\section{Chris Binnie}

MA DIC HonDEng FREng FICE FCIWEM

Independent Consultant, UK

\section{Martin Kimber}

CEng MICE

Atkins Water, UK

\section{Hugh Thomas}

CWEM CSci FCIWEM AMIChemE

Atkins Water, UK 
Published by ICE Publishing, One Great George Street, Westminster, London SW1P 3AA.

Full detail of ICE Publishing representatives and distributors can be found at: www.icebookshop.com/bookshop_contact.asp

\section{Other titles by ICE Publishing:}

Sustainable Water.

C. Ainger and R. Fenner (eds). ISBN 978-0-7277-5773-9

Land Drainage and Flood Defence Responsibilities, 5th edition. ICE. ISBN 978-0-7277-6063-0

Long-term Hazard to Drinking Water Resources from Landfills. P. Spillmann, T. Dorrie and M. Struve. ISBN 978-0-7277-3513-3

www.icebookshop.com

A catalogue record for this book is available from the British Library

ISBN 978-0-7277-6334-1

(C) Thomas Telford Limited 2018

ICE Publishing is a division of Thomas Telford Ltd, a wholly owned subsidiary of the Institution of Civil Engineers (ICE).

All rights, including translation, reserved. Except as permitted by the Copyright, Designs and Patents Act 1988, no part of this publication may be reproduced, stored in a retrieval system or transmitted in any form or by any means, electronic, mechanical, photocopying or otherwise, without the prior written permission of the Publisher, ICE Publishing, One Great George Street, Westminster, London SW1P 3AA.

This book is published on the understanding that the authors are solely responsible for the statements made and opinions expressed in it and that its publication does not necessarily imply that such statements and/or opinions are or reflect the views or opinions of the publishers. While every effort has been made to ensure that the statements made and the opinions expressed in this publication provide a safe and accurate guide, no liability or responsibility can be accepted in this respect by the authors or publishers.

While every reasonable effort has been undertaken by the authors and the publisher to acknowledge copyright on material reproduced, if there has been an oversight please contact the publisher and we will endeavour to correct this upon a reprint.

Commissioning Editor: Michael Fenton

Production Editor: Madhubanti Bhattacharyya

Market Development Executive: Elizabeth Hobson

Typeset by The Manila Typesetting Company

Index created by Nigel d'Auvergne

Printed and bound in Great Britain by Bell and Bain, Glasgow 


\section{Contents}

Foreword to the sixth edition

ix

Preface

xi

About the authors

xiii

01

Introduction and structure of the British and Irish water industries

1.1. Introduction

1.2. Structure and regulation of the water industry in the United Kingdom and Ireland 4

References

02

Quality of water

2.1. Origin and type of impurities 9

2.2. River and source quality 14

2.3. Potable-water standards 15

2.4. Key water quality parameters 20

2.5. Microbiological parameters 22

2.6. Concluding comments 24

References $\quad 24$

03

Overview of water treatment 27

3.1. Introduction 27

3.2. Water safety plans 28

3.3. Conventional water treatment 34

3.4. Modern water treatment 35

3.5. Overview of processes and process selection $\quad 36$

3.6. Typical process streams 36

3.7. Raw and treated water quality 38

3.8. Developing world treatment 40

3.9. Future treatment processes 42

3.10. Greenhouse gases (GHGs) 44

References 44

$04 \ldots \ldots \ldots \ldots \ldots \ldots \ldots \ldots \ldots$ Preliminary treatment $\quad 45$

4.1. Coarse intake screens 45

4.2. Raw water storage 45

4.3. Algae, algal control, and reservoirs 47

4.4. Fine screens 50

4.5. Pre-chlorination 55

4.6. Aeration 55

4.7. Algal treatment 57

4.8. Pre-settlement basins 58

References $\quad 59$

05

Coagulation and flocculation 61

5.1. Introduction 61

5.2. Definitions - coagulation and flocculation 63

5.3. Types of destabilisation 63 
5.4. Coagulation and flocculation - process variables

5.5. Types of rapid mixers (for coagulation) 66

5.6. Types of rapid mixers 67

5.7. Types of flocculator 68

5.8. Jar testing 69

5.9. Enhanced coagulation 70

5.10. Coagulants and coagulant aids 70

5.11. Coagulation with iron and aluminium salts 71

5.12. Other coagulants 76

5.13. Which coagulant? 76

5.14. Other chemicals used in coagulation
and flocculation

5.15. Control of coagulation and flocculation $\quad 79$

5.16. Chemical storage and dosing 80

5.17. The future of coagulation? 82

References 82

06

\section{Clarification}

85

6.1. Theory and principles of clarification 85

6.2. Clarifier selection and design considerations 97 References

$07 \ldots \ldots \ldots \ldots \ldots \ldots \ldots \ldots \ldots$ Filtration

7.1. Introduction

7.2. Types of granular filter

7.3. Granular filtration theory 122

7.4. Practical aspects 124

7.5. Coagulation prior to filtration 124

7.6. Rapid sand filters 125

7.7. Modes of operation 135

7.8. Pressure filters 138

7.9. Slow sand filters 139

7.10. Other filters 143

References 145

$08 \ldots \ldots \ldots \ldots \ldots \ldots \ldots \ldots \ldots \ldots$ Activated carbon adsorption $\quad 147$

8.1. Introduction 147

8.2. Activated carbon 147

8.3. Design of activated carbon adsorption
systems

8.4. Practical aspects of GAC adsorbers 154

8.5. Recent developments in adsorption 155

Reference 155

$09 \ldots \ldots \ldots \ldots \ldots \ldots \ldots \ldots \ldots$ Membrane processes $\quad 157$

9.1. Introduction 157

9.2. Reverse osmosis 159

9.3. Microfiltration and ultrafiltration 166 


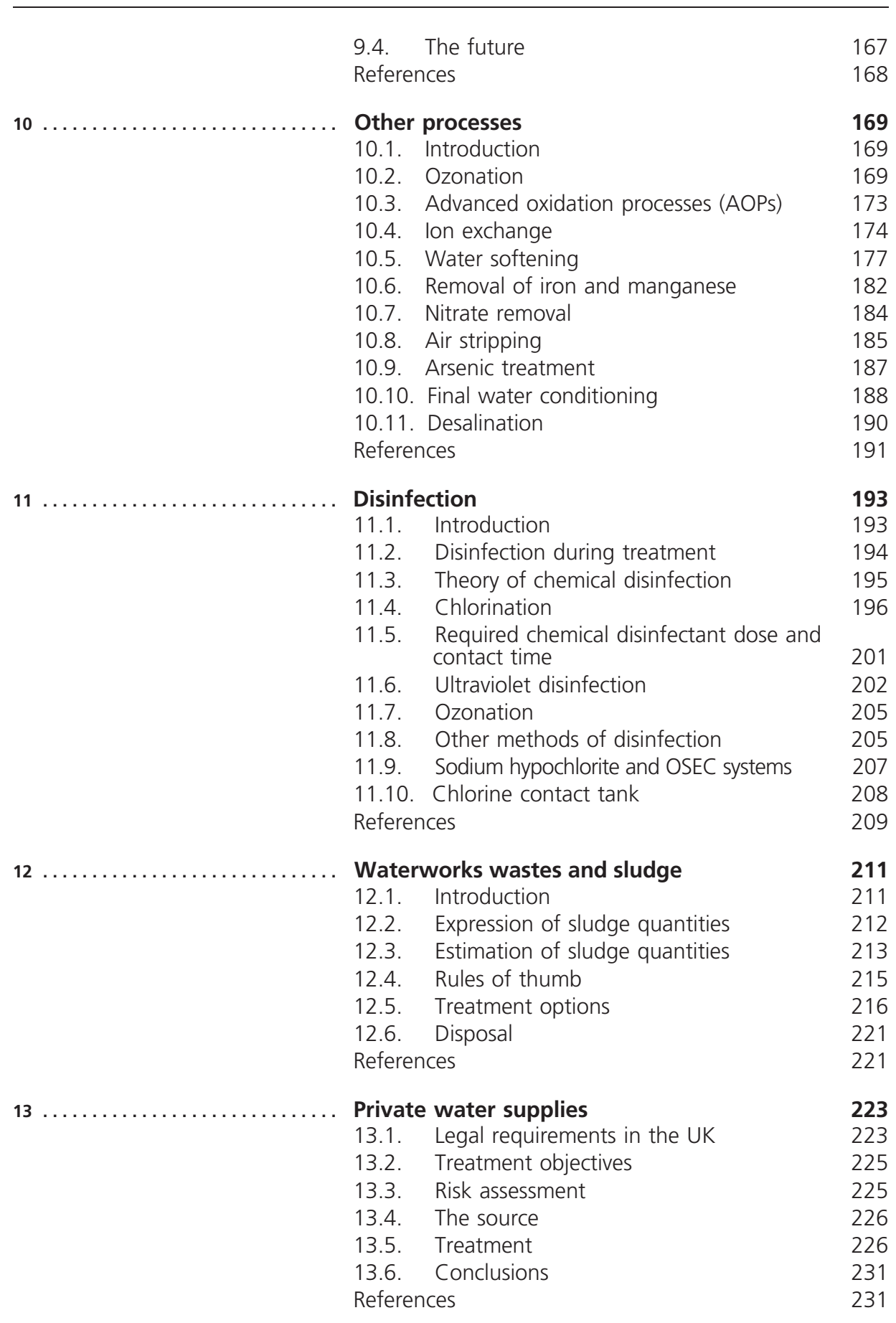


14

The sizing of water treatment plants

14.1. Introduction

14.2. Water supply

14.3. Components of demand

14.4. Domestic demand and projection

14.5. Non-household use

14.6. Losses from water systems

14.7. Measurement of leakage

14.8. Demand management

14.9. Available water resources

14.10. Water resource planning

14.11. Sizing the deployable output of a water treatment works

References

15

Appendix 1

Appendix 2

2

(n)

Appendix 3

Appendix 4

\section{Reuse of water}

15.1. Introduction

15.2. Planned reuse for potable supply

15.3. Direct reuse at Windhoek (Du Pisani, 2005)

15.4. Planned indirect potable reuse

15.5. Direct non-potable domestic reuse

Sample calculations

Comparison of drinking water quality standards

Glossary

SI units and basic conversion factors

Index
References
233 


\section{Foreword to the sixth edition}

The sixth edition of Basic Water Treatment is a timely update to this trusted, internationally renowned, and well-used source of information for all professions involved in the design, construction, and operation of water treatment facilities.

The authors provide a comprehensive review of the principles of the approach to be drawn upon when developing and appraising effective and efficient design options for new or enhanced treatment processes, together with sound advice on current good treatment practices.

For this edition, the updates to the sections on activated carbon and membrane processes, in particular, will be welcomed by many readers. The authors also provide a useful reminder of the fundamental concepts of risk management as these apply to the supply of clean safe drinking water, by setting out how incorporating a water safety plan approach underpins the design and operation of water treatment facilities. This nudge for the reader to be aware of the wider context for the setting of expectations of the role of treatment in modern integrated source-to-tap management of water supplies nicely complements the reader's need to have access to detailed explanations of process options.

The proactive, preventative features of good water treatment practice also put emphasis on another aspect of risk management that is critical to maintaining the trust and confidence of consumers in their water supply, that is, resilience of the supply. For treatment facilities to be fit for purpose today, they need not only to produce water of the required standards consistently and sustainably, but to be designed and operated with the capacity to contain and recover interruptions to treatment, while minimising the consequences for consumers. Again, an understanding and awareness of how developing or using water treatment facilities relates to the wider service requirements of the water supplier and the community it serves is entirely pertinent to our professional roles today.

Basic Water Treatment provides essential knowledge that is of value to both students and practitioners, and I am pleased to commend this sixth edition as a reliable guide for all concerned with understanding the fundamentals of water treatment.

$$
\begin{array}{r}
\text { Milo Purcell } \\
\text { Deputy Chief Inspector of Drinking Water for } \\
\text { England and Wales }
\end{array}
$$


Downloaded by [] on [26/04/23]. Copyright (C ICE Publishing, all rights reserved. 


\section{Preface}

The sixth edition of this book, which has become one of the accepted primers on water treatment, is a significant update of the fifth edition, reflecting recent changes in water treatment and changing priorities. A new chapter has been added to expand coverage of GAC adsorption. The coverage of membrane processes has been expanded and a section added on advanced oxidation processes. However, this remains a relatively slim volume covering water treatment a very broad subject - and thus a degree of subjectivity has had to be exercised over what should be covered.

Basic Water Treatment is aimed at university students, at practising water treatment engineers, for whom it will be a useful reference book, and at mechanical engineers and chemists who need to put their specialised knowledge into a broader context. It will also be of interest to those managers and non-technical staff who wish to understand some of the quality and technical issues relating to water treatment. It is not a prescriptive handbook on water treatment plant design; rather, it provides essential background and is a useful firstchoice reference book for many aspects of water quality and treatment.

It is important that all involved in water quality and water treatment do not adopt too blinkered an approach. In Western Europe, we now have to focus very closely on compliance with prescriptive water quality standards, although the Water Framework Directive and public concerns over the environment require a wider consideration of water resources and water demands. Indeed, over much of the world, water engineers should consider, or at least be aware of, much wider issues, weighing the costs of highquality water against the overriding need to supply safe water to as many as possible.

Basic Water Treatment primarily relates to water treatment in Western Europe and North America but it also takes account of treatment in other developed areas as well as in developing and less developed areas. 
Downloaded by [] on [26/04/23]. Copyright (C ICE Publishing, all rights reserved. 


\section{About the authors}

Chris Binnie MA DIC HonDEng FREng FICE FCIWEM has worked and lectured extensively in many countries. A past president of the Chartered Institution of Water and Environmental Management and a Fellow of the Royal Academy of Engineering and of the Institution of Civil Engineers, he is now a Visiting Professor at the University of Exeter's Centre for Water Systems.

Martin Kimber CEng MICE is a water treatment specialist with over 30 years' experience of working on all aspects of water quality and treatment, most recently with Atkins Water. Prior to joining Atkins, where he gained many years of experience both in the UK and overseas, he worked for companies in the USA and in Kenya. His experience encompasses the full range of water treatment plants from simple developing world slow sand processes to modern advanced water treatment.

\section{Hugh Thomas CWEM CSci FCIWEM AMIChemE} is a Chief Process Engineer with 20 years' experience in the water and wastewater treatment industry. He is currently Technical Authority for Process Engineering within Atkins Water, with national responsibility for leading technical excellence, innovation, and quality. During his career, he has held positions in client, consultant, and contractor organisations. $\mathrm{He}$ is on the committee of the IChemE Water Special Interest Group and the Industry Advisory Panel at Cranfield University. 